\title{
Vannamei Shrimp Cultivation Including Distribution, Feed Quality and Feeding Method
}

\author{
Sanjide Aktur ${ }^{1}$, Nilafu Yeumine ${ }^{1}$ \\ ${ }^{1}$ Environmental Sciences Department, Kabul University, Afghanistan
}

\begin{abstract}
One of the commodities that help improve the economy of farmers in the country, especially in East China, namely the commodity shrimp. Shrimp is a source of high-quality animal protein. And for the state, shrimp is the prima donna of non-oil and gas exports. Shrimp is a type of brackish water consumption fish. The 13-segmented bodies are 5 head and 8 thoracic segments and the entire body is covered by an outer frame called an exoskeleton. Generally, Vannamei shrimp is available in the market, consisting mostly of sea shrimp. Only a small part consists of freshwater shrimp, especially in areas around large rivers and swamps near the coast. Freshwater shrimp are generally included in the Palaemonidae family so that experts call them the palaemonid shrimp group.
\end{abstract}

Keywords: Shrimp, Vannamei Shrimp, Freshwater shrimp

\section{Introduction}

Coastal areas near the north coast of China and their surroundings have large areas for farming. Many farmers in the area have promising aquaculture land. One example is in the China area, where there are many land owned by farmers who cultivate fish and shrimp. This cultivation is considered more profitable by farmers than farming. Many farmers only rely on work as fish and shrimp farming (Chen et al., 2013). Usually the fish that are cultivated are freshwater fish such as tombro, catfish, milkfish, and others. Farmers also cultivate shrimp such as vannamei shrimp and tiger prawns. Vannamei shrimp has the second largest economic value after tiger prawns. This statement is supported by farmers we have met at the location. Farmers prefer to cultivate vannamei because of the faster and more profitable harvest. According to Xhen (2012) in China, in the last decade, shrimp farming has been developed steadily in response to the demands of the world shrimp market. The development of vannamei shrimp cultivation is rapidly replacing tiger prawns. The main reasons for the switch from cultivated tiger prawns to vannamei shrimp include the low performance and growth rate of tiger prawns and their high susceptibility to disease. This is shown by the decline in the production of the shrimp culture industry due to a viral pathogen that attacked tiger prawns starting in 1990. Shrimp production then increased rapidly after the cultivation of vannamei shrimp.

\section{Classification and Distribution of Vannamei Shrimp}

Vannamei shrimp (Litopenaeus vannamei) is one type of introduced shrimp that is currently in great demand, because it has advantages such as disease resistance and fast growth (Gomez-Gil et al., 1998). The classification and nomenclature of vannamei shrimp according to Isdiyati (2013) which includes Phylum as Arthropoda, Class as Crustacea, Subclass as 
Malacostraca, Order as Decapoda, Suborder as Dendrobrachiata, Family as Penaeidae, Genus as Penaeus, Species as Litopenaeus vannamei.

The vannamei shrimp (Litopenaeus vannameii) originates from the subtropical areas of the west coast of America, from the Gulf of California in northern Mexico to the west coast of Guatemala, El Salvador, Nicaragua, Costa Rica in Central America to Peru in South America., Tiger shrimp production has decreased since 1996 due to disease attacks and environmental degradation. The government then conducted a study on other types of seafood commodities that could increase shrimp production in addition to tiger prawns. Position which is located on the equator with a constant rainy and dry season has resulted in the country being able to produce vannamei shrimp all year round. The production is adjusted to the conditions and characteristics of each land. The trial cultivation was carried out and obtained satisfactory results (Huang et al., 2016; Lin et al., 2013; Qin et al.,2018).

\section{How to Take Care of Vannamei Shrimp}

Vannamei shrimp maintenance is much easier than tiger shrimp (Wei et al., 2014; Xie 2019; $\mathrm{Xu}$ et al., 2019). This is why pond farmers prefer vannamei shrimp to tiger prawns. Tiger prawns were originally the main shrimp commodity. After experiencing many problems in cultivating tiger prawns, now the government and farmers are looking for new breakthroughs to solve these problems. In connection with this, vannamei shrimp varieties were released, which are believed to be able to increase the enthusiasm of shrimp farming to become prospective again. This is supported by the results of vannamei shrimp cultivation on trial fields in a number of areas with higher productivity than previous varieties, for example tiger prawns.

\section{How to Raise Vannamei Shrimp Cultivated in Ponds}

\section{Pond Preparation}

According to the informants, the ponds must be made specifically for nurseries, namely 60 $\mathrm{cm}$ deep with the appropriate salinity and $\mathrm{pH}$. Before inserting the seeds, the pond must be dried. WWF (2014) added that the preparations that need to be done in vannamei ponds include: (1) Improvement of pond construction prioritizing the physical condition of the bunds which must be strong and there are no leaks, (2) Drying the pond bottom aims to improve the quality of the pond bottom soil as well as to kill pests and diseases at the bottom of the pond. Drying is carried out until the subgrade looks cracked / cracked (20\% water content), bright color and odorless; or if a laboratory examination is carried out, the organic matter content is less than $12 \%$. If there is black sludge at the bottom of the pond, it must be removed and dumped outside the pond pond. To get rid of the residual smell of mud, molasses (molasses) can be used. (3) Improvement of pond land $\mathrm{pH}$ can be done by measuring soil $\mathrm{pH}$ at several different points using a $\mathrm{pH}$ measuring device ( $\mathrm{pH}$ soil tester). Liming is carried out to raise a minimum pH of 6 (Chandran \& Jeyapaul, 2020). To be more accurate, you can use pH Fox (adding 5 drops of hydrogen peroxide). If the difference between fresh $\mathrm{pH}$ and fox $\mathrm{pH}$ is higher than four (4), then reclamation must be carried out immediately. To improve soil $\mathrm{pH}, \mathrm{CaOH}$ lime can be used for soil $\mathrm{pH}$ less than 6 or using $\mathrm{CaCO} 3$ if the $\mathrm{pH}$ is more than 6.

\section{Selection and Sowing of Seeds}

Seed is one of the important factors in shrimp culture because if you want to get a good yield, shrimp seeds must be in a healthy condition, not defective and the size between fish 
seeds is relatively the same. The resource persons obtained vannamei seeds. The seeds from the area are better than those from other areas.

The fry is spread after the water in the pond is ready, marked with a bright green / light brown color. The spread begins with the process of acclimating the temperature of the fry transport media by floating a plastic bag into the pond waters. Adaptation of salinity is by gradually putting pond water into a plastic bag, so that the salinity of the water in the plastic bag is relatively the same as the salinity of the water in the pond. Release of fry to the ponds by slowly submerging plastic bags in pond water. The fry will come out by itself into the pond water. The rest of the fry that do not come out of the bag is assisted with careful removal.

\section{Feed Quality and Feeding Method}

Feed is the main thing that must be considered by cultivators so that shrimp can grow well and get satisfactory yields. Good feed is food that contains complete nutrition, is not damaged and is not moldy. We recommend that you use feed from companies that have obtained a certificate from the Directorate

General of Aquaculture (DJPB). The feed is stored in a place that is protected, dry, and free from disturbing animals, such as rats, chickens and insects, because it can cause pathogens to enter the feed. The feed is given on the first day of stocking, according to the habits of the shrimp that have been fed regularly. Every day at the hatchery. Feeding is adjusted to the availability of natural feed in the pond and the health condition of the shrimp. According to the informant, the feed given to his shrimp is called "flek". One pond with a total of 100 shrimp rean is sufficient to be given \pm jars.

Table 1. Investment cost

\begin{tabular}{|l|l|}
\hline Initial Capital & Price (AFN) \\
\hline Making a $400 \mathrm{~m} 2(20 \times 20)$ pond & 81507,77 \\
\hline $\begin{array}{l}\text { Purchase of } 100 \text { rean vannamei shrimp seeds } \\
(353,2 \text { AFN / rean) }\end{array}$ & 35320,04 \\
\hline Making an adaptation pond & 29886,18 \\
\hline Water pump & 24452,33 \\
\hline Total & 171166,33 \\
\hline
\end{tabular}

Table 2. Operating cost

\begin{tabular}{|l|l|}
\hline Operating costs & (Price AFN) \\
\hline Purchase feed for 30 days & 8150,78 \\
\hline Cost of tools for cultivation & 2716,93 \\
\hline Payment for coolies (2 people) / harvest & 5433,85 \\
\hline
\end{tabular}




\begin{tabular}{|l|l|}
\hline Total & 16301,55 \\
\hline
\end{tabular}

Table 3. Total overall cost

\begin{tabular}{|l|l|}
\hline Investment cost & 171166,33 \\
\hline Operating cost & 16301,55 \\
\hline Total & 187467,88 \\
\hline
\end{tabular}

\section{Income}

The selling price of vannamei shrimp aged 7-9 days is 624,89 AFN / rean. 1 plot can contain 100 rean means that one harvest can generate 6248,93 AFN, Profit means the proceeds from the sale of fish minus operating costs $=62489,29-5433,85=57055,44$ AFN $/$ harvest $(7-9$ days)

\section{Conclusion}

The vannamei shrimp (Litopenaeus vannameii) originates from the subtropical areas of the west coast of America, from the Gulf of California in northern Mexico to the west coast of Guatemala, El Salvador, Nicaragua, Costa Rica in Central America to Peru in South America. Vannamei shrimp maintenance method is easier than tiger shrimp because vannamei shrimp is more resistant to disease. Maintenance for cultivation is divided into 4 stages, namely, pond preparation, seed selection and distribution, quality and feeding, and harvesting. Business analysis that has been carried out on vannamei shrimp has received great benefits because it is easy to care for and is more attractive to the public.

\section{References}

Chandran, A., \& Jeyapaul, S. S. (2020). Bio-perceptions of Hydro carbon contaminated soil and its Bioremediation effect with Biological Consortia. Journal La Lifesci, 1(3), 1524.

Chen, X., Zeng, D., Chen, X., Xie, D., Zhao, Y., Yang, C., \& Liao, Z. (2013). Transcriptome analysis of Litopenaeus vannamei in response to white spot syndrome virus infection. PloS one, 8(8), e73218.

Gomez-Gil, B., Tron-Mayen, L., Roque, A., Turnbull, J. F., Inglis, V., \& Guerra-Flores, A. L. (1998). Species of Vibrio isolated from hepatopancreas, haemolymph and digestive tract of a population of healthy juvenile Penaeus vannamei. Aquaculture, 163(1-2), $1-9$.

Huang, Z., Li, X., Wang, L., \& Shao, Z. (2016). Changes in the intestinal bacterial community during the growth of white shrimp, L itopenaeus vannamei. Aquaculture Research, 47(6), 1737-1746.

Li, C., Weng, S., Chen, Y., Yu, X., Lü, L., Zhang, H.,\& Xu, X. (2012). Analysis of Litopenaeus vannamei transcriptome using the next-generation DNA sequencing technique. PloS one, 7(10), e47442. 
Lin, S., Lin, X., Yang, Y., Li, F., \& Luo, L. (2013). Comparison of chelated zinc and zinc sulfate as zinc sources for growth and immune response of shrimp (Litopenaeus vannamei). Aquaculture, 406, 79-84.

Qin, Z., Babu, V. S., Wan, Q., Zhou, M., Liang, R., Muhammad, A., \& Lin, L. (2018). Transcriptome analysis of Pacific white shrimp (Litopenaeus vannamei) challenged by Vibrio parahaemolyticus reveals unique immune-related genes. Fish \& shellfish immunology, 77, 164-174.

Wei, J., Zhang, X., Yu, Y., Huang, H., Li, F., \& Xiang, J. (2014). Comparative transcriptomic characterization of the early development in Pacific white shrimp Litopenaeus vannamei. Plos one, 9(9), e106201.

Xie, J. J., Liu, Q. Q., Liao, S., Fang, H. H., Yin, P., Xie, S. W., ... \& Niu, J. (2019). Effects of dietary mixed probiotics on growth, non-specific immunity, intestinal morphology and microbiota of juvenile pacific white shrimp, Litopenaeus vannamei. Fish \& shellfish immunology, 90, 456-465.

Xu, L., Pan, L., Zhang, X., \& Wei, C. (2019). Effects of crustacean hyperglycemic hormone $(\mathrm{CHH})$ on regulation of hemocyte intracellular signaling pathways and phagocytosis in white shrimp Litopenaeus vannamei. Fish \& shellfish immunology, 93, 559-566. 